\title{
Archiwalia
}

\section{Listy Witolda Gombrowicza do Leo Lipskiego'}

Piotr Sadzik
Redakcja dziękuje

Ricie Gombrowicz

i Instytutowi Literackiemu w Maisons-Laffitte za zgodę na publikację listów.

TEKSTY DRUGIE 2020, NR 6, S. 387-409

DOI: $10.18318 /$ td.2020.6.23 | ORCID: 0000-0002-7897-7992

\section{Komentarz}

Listowny dialog Witolda Gombrowicza i Leo Lipskiego należy do tych spotkań na szczycie, które w historii polskiej literatury przeszły niemal niezauważone. Tysiące stron napisanych przez Gombrowicza i gigantyczna biblioteka poświęconych mu prac niemal nie odnotowują relacji z Lipskim. Symetrię zachowuje niepomiernie skromniejszy objętościowo korpus wydanych tekstów tego ostatniego, w którym Gombrowicz również pojawia się jedynie na marginesie. Tymczasem, mimo że rola tego dialogu w biografiach obydwu miała charakter epizodyczny, ograniczony do kilku miesięcy na przełomie 1954 i 1955 roku², trudno nie docenić jego wagi. W rozmowie uczestniczą przecież autorzy potężnego kalibru,

1 Listy Witolda Gombrowicza: do Leo Lipschutza, 1954-1955 [załączone: notatka dotycząca Martina Bubera, list Martina Bubera do Leo Lipschutza, notatka Lipschutza w tej sprawie], w: Witold Gombrowicz - materiały dot. i fragm. korespondencji, ILK Gombro 02/15, Archiwum Instytutu Literackiego „Kultura” w Maisons-Laffitte.

2 Jak pisał sam Lipski: „potem się to urwało”, L. Lipski Paryżze złota:teksty rozproszone, wyb. i oprac. H. Gosk, Świat Literacki, Izabelin 2002, s. 179.

\section{Piotr Sadzik -}

doktorant w Instytucie Literatury Polskiej UW. Obecnie zajmuje się stanami wyjątkowymi literatury, filozofią literatury w kontekście refleksji postsekularnej oraz myślą Jacques'a Derridy. Współredaktor Spojrzenia Antonioniego (wraz z Pauliną Kwiatkowską) oraz Widm Derridy (wraz z Agatą Bielik-Robson), a także redaktor tomu Imiona anomii. Literatura wobec doświadczenia stanu wyjatkowego. Przygotowuje książkę o „maranach literatury polskiej,"a także doktorat o twórczości Witolda Gombrowicza. W Uniwersytecie Muri im. Franza Kafki kieruje Katedrą Nawiasu. 
w najbardziej bezkompromisowy i odważny sposób zapuszczający się za pomocą literatury w rewiry niedostępnych jej dotąd doświadczeń. Co więcej, wyjątkowość tej krótkiej rozmowy polega także na obecności przemykającej w jej tle trzeciej osoby dramatu, wybitnego kontynuatora i komentatora tradycji chasydzkiej Martina Bubera.

Wśród znanych dotychczas materiałów związanych z tym egzotycznym

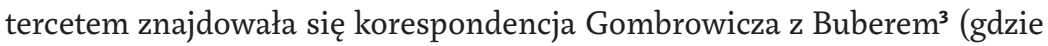
wspomina się o Lipskim jako o osobie pośredniczącej w tej wymianie), list Bubera do Lipskiego wraz z wystawioną przez tego pierwszego opinią na temat Trans-Atlantyku ${ }^{4}$, a także pisany z okazji śmierci Gombrowicza list Lipskiego do „Redaktora”, identyfikowanego jako Michał Chmielowiec ${ }^{5}$. Przeprowadzone ostatnio kwerendy archiwalne pozwalają poszerzyć ten korpus tekstów i wypełnić istniejące luki w naszej wiedzy na temat omawianej sprawy. Archiwum Instytutu Literackiego w podparyskim Maisons-Laffitte przechowuje cztery listy Gombrowicza do Lipskiego, a także sporządzoną przez autora Piotrusia notatkę wyjaśniającą szczegóły tej relacji, przekazaną Jerzemu Giedroyciowi ${ }^{6}$. Również przechowywana tam obfita korespondencja Lipskiego z redaktorem „Kultury”, która nie była dotychczas obiektem kwerend, zawiera informacje niezbędne dla właściwego ukontekstowienia

3 R. Gombrowicz Gombrowicz w Argentynie, Wydawnictwo Literackie, Kraków 2005, s. 162-169.

4 L. Lipski Paryż ze złota, s. 170. Opinia ta w innym miejscu została błędnie związana ze Ślubem. Zob. R. Gombrowicz, Gombrowicz w Argentynie, s. 169.

5 L. Lipski Paryż ze złota, s. 178-179. Wypowiedź Lipskiego zawiera odpowiedzi na ankietę rozpisaną po śmierci Gombrowicza przez londyńskie „Wiadomości”, których redaktorem był wówczas istotnie Chmielowiec. Trafność tej identyfikacji komplikuje jednak fakt, że w liście o Chmielowcu wspomina się jako o osobie trzeciej, ponadto to właśnie Chmielowiec skontaktował Lipskiego z Gombrowiczem, bezzasadne byłoby więc prezentowanie przed nim takiej rekonstrukcji. Podanie tych szczegółów można by jednak uzasadnić zakładanym publicznym charakterem wypowiedzi, adresowanej jednocześnie do czytelników pisma. Zob. L. Lipski, odpowiedź w Ankiecie o Witoldzie Gombrowiczu, „Wiadomości” 1970 r. 25 nr 5.

6 Listy Witolda Gombrowicza: do Leo Lipschutza, 1954-1955 [załączone: notatka dotycząca Martina Bubera, list Martina Bubera do Leo Lipschutza, notatka Lipschutza w tej sprawie], w: Witold Gombrowicz - materiały dot. i fragm. korespondencji, I LK Gombro 02/15, A rchiwum Instytutu Literackiego "Kultura” W Maisons-Laffitte. Dalej jako "Listy Witolda Gombrowicza do Leo Lipskiego" oraz "Leo Lipski, Notatka wyjaśniająca", z podaniem dat dziennych. W Maisons-Laffite znajduje się również wydany już wcześniej list Bubera do Lipskiego wraz z uwagami na temat Trans-Atlantyku. Za udostępnienie materiałów dziękujęp. Annie Bernhardt, p. Leszkowi Czarneckiemu oraz innym członkom Stowarzyszenia Instytut Literacki „Kultura”. 
prezentowanych tu tekstów. Podobnie rzecz ma się z zasobami toruńskiego Archiwum Emigracji, gdzie przechowywane są m.in. listy Lipskiego do publicysty londyńskich „Wiadomości” Michała Chmielowca, który skontaktował swojego rozmówcę z Gombrowiczem.

Główną osią prezentowanej tu korespondencji jest „sprawa Bubera”, pomysł Gombrowicza, by zainteresować swoim pisarstwem autora Ja i Ty, a następnie, dzięki jego ewentualnemu poparciu zabiegać o przekłady własnych książek. Cała historia rozegrała się w dwóch aktach. Za pierwszym razem, w 1951 roku, rozmowa ograniczyła się do krótkiej wymiany zdań, złożonej z dwóch listów Gombrowicza i jednej odpowiedzi Bubera. Drugi akt, nieco intensywniejszy i bardziej interesujący nas w tym miejscu ze względu na pojawienie się w nim Lipskiego, rozegrał się trzy lata później. Lipski jest tu zresztą nie tylko powiernikiem Gombrowicza, ale także pośrednikiem, który kontaktuje go z Buberem i przekazuje listy między jednym a drugim Finalny etap całej sprawy nastąpi w 1969 roku, kiedy po śmierci Gombrowicza Lipski napisze do Giedroycia z informacją o tym, że posiada prezentowane tu dokumenty.

Wciąż, niestety, nie udało się ustalić, w jaki sposób Lipski nawiązał znajomość z Buberem, odpowiedzi na to pytanie mogłyby pewnie udzielić dodatkowe kwerendy w archiwach Izraela. Oczywiście skrajnie różne było usytuowanie obydwu w przestrzeni tego nowo powstałego wówczas państwa. Dystans, jaki ich dzielił, był przecież dystansem między nieznającym miejscowego języka dość anonimowym inwalidą, tkwiącym w skrajnej nędzy

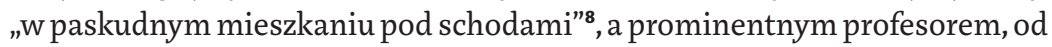
1938 roku, po emigracji z III Rzeszy, wykładowcą Uniwersytetu Hebrajskiego w Jerozolimie. Pracownikiem tego ostatniego był w tamtym czasie Dow Sadan, z którym Lipski utrzymywał przez lata znajomość', możliwe też, że w rolę pośrednika wszedł inny znajomy Lipskiego, Dawid Lazer, pochodzący z Krakowa redaktor telawiwskiej gazety „Maariw”, doskonale ustosunkowany w elitach kulturalnych Izraela (wśród znanych mu osób znajdziemy m.in. Maxa Broda, Szmuela Josefa Agnona czy Abrahama Suckewera). Pewne,

7 L. Lipski Paryżze złota, s. 179: „Gombrowicz i Buber porozumiewali się ze sobą wyłącznie przeze mnie".

8 Cyt. za: E. Kossewska Ona jeszcze mówi po polsku, ale śmieje się po hebrajsku. Partyjna prasa polskojęzyczna i integracja kulturowa Żydów w Izraelu (1948-1970), Wydawnictwa Uniwersytetu Warszawskiego, Warszawa 2015, s. 348.

9 Za informacje w tej sprawie serdeczne podziękowania składam Antoniemu Zającowi. 
że kiedy w 1964 roku, a więc dziesięć lat po interesujących nas tutaj wydarzeniach, Lipskiego odwiedził dziennikarz miejscowej polskojęzycznej prasy, odnotował na jego półce obecność pracy Bubera ${ }^{10}$. Rekonstrukcja tych związków wydaje się tym bardziej konieczna, że pisarstwo Lipskiego naznacza tradycja nieortodoksyjnego judaizmu, który stanowił też kluczowy obszar zainteresowań jego rozmówcy ${ }^{11}$. Być może jakieś wskazówki mogłyby podsunąć listy, jakie Lipski słał do Gombrowicza, te jednak niestety nie zostały odnalezione.

Buber zajmuje wówczas jedną z czołowych pozycji w rankingach najbardziej wpływowych intelektualistów, od kilku lat wymienia się go wśród kandydatów do Literackiej Nagrody Nobla. W dobie triumfów egzystencjalizmu jego wywiedziona z teologii judaistycznej filozofia dialogu wydaje się dobrze rymować z najbardziej nośnymi hasłami intelektualnymi epoki. Nie wyczerpuje sięjednak wcale w tej paralelności, inspiruje wielu poszukujących swojego języka twórców powojnia. „Jak by to na przykład było. Jak by to było pojechać do Jerozolimy, pójść do Martina Bubera i powiedzieć mu: «Wujku Buberze, jestem, teraz jestem u Ciebie»" - pisał pod koniec 1945 roku żydowski „ocaleniec” z Rumunii Paul Antschel, który lada moment, już jako Paul Celan, uczyni z Buberowskiej filozofii spotkania jeden z kluczowych składników swojej koncepcji poezji po Zagładzie ${ }^{12}$. Za kilka lat także Gombrowicz miał dostrzec powinowactwo własnej myśli z Buberem:

i tu masz naszego nieszczęsnego Gombrowicza, choć to sarmata. Cała jego wielkość wynikała z filozofii spotkania. Czy pamiętasz ten jego wiernopoddańczy list napisany do Bubera? Niepodległy duch Gombra korzył się przed Buberem, a było to poszukiwaniem sprzymierzeńca. Witold Gombrowicz na własną rękę odkrył motywy filozofii spotkania, [...] chciał wydostać się ze swego piekła. Tak, był zatrzaśnięty. Patologicznie

Wymienia się tam jednak Historię chasydyzmu, a więc książkę, której Buber nie napisał i której można się dopatrywać w kilku z jego licznych prac na temat żydowskiego mistycyzmu. Dodajmy, że nie jest też jasne, w jakim języku czytał Bubera Lipski, zważywszy na ówczesny brak polskich przekładów tekstów tego pierwszego. H. Joffe Kafka z ulicy Bugraszow, "Nowiny i Kurier” 10.01.1964, za: M. Cuber Trofea wyobraźni. O prozie Leo Lipskiego, Wydawnictwo Uniwersytetu Śląskiego, Katowice 2011, s. 53.

11 A. Lipszyc Leo Lipski: Część śmierci, w: Czerwone listy. Eseje frankistowskie o literaturze polskiej, Austeria, Kraków 2018, s. 69-101. peszt 2010, s. 69. 
zatrzaśnięty. To prawie cała prawda o Gombrowiczu. Musiał szukać wspólnika w Martinie Buberze. ${ }^{13}$

Gombrowicz zatrzaśnięty był jednak przede wszystkim na bardziej elementarnym poziomie. Po ponad 10 latach pobytu w Argentynie zabiega o powrót do literatury, próbując zainteresować kolejne osoby napisanym właśnie dramatem Ślub. Nie pomaga mu fakt, że utknął na stanowisku urzędnika w Banco Polaco w Buenos Aires, która to praca pochłania większość jego czasu, stopniowo doprowadzając go do przygnębiającego paraliżu: „bank mi się wykańcza, zanadto mnie męczy, erotyka mi się wykańcza i literatura... Myślę o śmierci i c z e k a m. Nie zdziałałem N I C. Złe przeczucia"14. Rozpaczliwie szuka więc u Bubera katapulty, która mogłaby przywrócić jego pisanie do głównego obiegu dyskusji literackich.

Pierwszy akt tego korespondencyjnego spotkania rozegrał się za sprawą dzielącego wówczas z Gombrowiczem życie Alejandra Rússovicha ${ }^{15}$. Zapoznawszy się za jego podpowiedzią z przełożonym właśnie na hiszpański Buberowskim Problemem człowieka, w maju 1951 roku Gombrowicz postanowił posłać do Jerozolimy maszynopis świeżo ukończonego Ślubu ${ }^{16}$. O geście tym zadecydowały w dużej mierze racje taktyczne. Gombrowicz starał się wykorzystać pozycję Bubera i jego ewentualne poparcie dla sprawy tłumaczenia swojego dramatu na francuski. W pierwszym liście zapewniał o „głębokim podziwie" dla pracy filozofa i „ogromnym wrażeniu”, jakie wywarła na nim lektura książki, której poszczególne partie uznał za „prawdziwą rewelację"17. Entuzjazmu, jaki towarzyszył mu przy okazji lektury Bubera, nie można jednak chyba zrzucić wyłącznie na karb umiejętnego rozporządzania własną popularnością. Wydaje się, że wciąż w tym czasie mocno intelektualnie osamotniony, oddalony od centrów światowej kultury Gombrowicz poszukiwał dla swoich idei sojusznika, z którym w tym wypadku odczuł faktyczną bliskość: „myśl Pana nie ma chyba w sztuce bardziej ode mnie oddanego jej

13 L. Buczkowski Żywe dialogi, Pomorze, Bydgoszcz 1989, s. 59.

14 W. Gombrowicz Kronos, Wydawnictwo Literackie, Kraków 2012, s. 17. W akapicie tym korzystam z ustaleń artykułu: P. Sadzik Witold Gombrowicz albo maranizm bergiem podszyty, w: Marani literatury polskiej, red. P. Bogalecki, A. Lipszyc, Wydawnictwo Austeria, Kraków-Budapeszt-Syrakuzy 2020, s. 535-580. 
sprzymierzeńca - może kulawo, ale posuwam się w tym samym kierunku. [...] Istnieje pewna zbieżność pomiędzy naszym widzeniem człowieka"18. Jakkolwiek więc relacja Gombrowicza z wybitnym badaczem historii chasydyzmu nie wydawałaby się nieintuicyjna czy nawet szokująca, niemało jest przesłanek dla jej zasadności. Sojusz z Buberem wpisywał się zresztą w znacznie szersze zjawisko - przekonanie Gombrowicza o jego związkach ze specyficznie rozumianą żydowskością: , ja poniekąd miałem z nimi jedną rzecz wspólną, a mianowicie - stosunek do formy [...], ten napięty stosunek Żyda do formy, to, że ona tak ich dręczy" ${ }^{\prime \prime}$. Już w kawiarniach międzywojennej Warszawy, jak sam wspominał, ze względu na pochodzenie jego przyjaciół miano go wręcz nazywać „królem żydowskim”20. Co więcej, jak podkreślał, to właśnie wśród Żydów odnajdywał najczujniejszych, najbardziej oddanych i najmocniej wspierających go czytelników: to Bruno Schulz wspomógł swoim entuzjazmem świeżo wydaną Ferdydurke, to Artur Sandauer odpowiadał za powrót dzieł Gombrowicza do krajowego obiegu czytelniczego po październikowej odwilży, to Józef Wittlin dostarczył swoim poparciem Gombrowiczowi tarczy osłaniającej go przed atakami środowisk polonijnych, kiedy ten debiutował na emigracji ${ }^{21}$. Ta wyrażona we Wspomnieniach polskich myśl zostaje też sformułowana w jednym z listów do Lipskiego: „mam wrażenie, że jedynych prawdziwych przyjaciół znajdę wśród Żydów. Dwaj ludzie, którzy naprawdę mnie poparli w literaturze polskiej, to Schulz i Wittlin"22.

Powinowactwo z Buberem miałoby opierać się na podobnym w obydwu przypadkach ujęciu nowej koncepcji podmiotowych relacji. Wyrastająca z teologii judaizmu dialogiczna formuła filozofii spotkania, która dowodziła nieuchronnej relacyjności i niesuwerenności „ja”, całkiem zgrabnie zrymowała się więc Gombrowiczowi z jedną z głównych idei jego autorskiej antropologii, etykietowanej jako „kościół międzyludzki”:

wydaje mi się bowiem, że punkt wyjścia tego dramatu jest p rawie ten sam [co u Bubera - P.S.]: jest to ta sama idea rzeczywistości, która

18 Tamże, s. $165-166$.

19 W. Gombrowicz Wspomnienia polskie. Wędrówki po Argentynie, Wydawnictwo Literackie, Kraków 2011, s. 174 .

Tamże, s. 174.

Tamże, s. 178.

List Witolda Gombrowicza do Leo Lipskiego, 21.09.1954 roku. 
tworzy się mi ę d zy ludźmi. [...] Zobaczy Pan też, że przed poznaniem pism Pana użyłem tego samego słowa "między” jako znaku i przeczucia nowej koncepcji człowieka. ${ }^{23}$

Odpowiedź Bubera przyniosła jednak Gombrowiczowi „spore rozczarowanie"24. Pochwalny ton listu hamowała kurtuazja i zdawkowość. Miała w tym chyba udział różnica perspektyw. Stosunkowo tradycyjne założenia filozofii dialogu kazały Buberowi postrzegać spotkanie jako relację dwóch jednostek ludzkich, wskutek czego całkowicie przegapiał on znacznie dalej idącą myśl Gombrowicza. W Ślubie, w którym indywidualną, senną psychomachię nawiedzają widma naznaczonej wojenną anomią epoki, Gombrowicz rozpisuje jednostkowe rozszczepienie, gdzie inność jest już nieusuwalnym elementem stosunku ,ja” wobec samego siebie. Sprowokowany nieporozumieniem Gombrowicz przedstawił jeszcze w odpowiedzi obszerną autoanalizę dramatu, przekonując dalej Bubera o istniejących między nimi powinowactwach, ale list jedynie domykał tę nie do końca udaną próbę nawiązania kontaktu.

Choć okazało się, że „zbieżności”25 nie zbudowały właściwego pomostu dla porozumienia z Buberem, a zachowawczość filozofa nie potrafiła uchwycić wywrotowego novum Ślubu, Gombrowicz pozostał jednak chyba wierny przekonaniu o bliskości ideowej z perspektywą swojego rozmówcy, jak i nadziei na jego pomoc ${ }^{26}$. I tu zaczyna się druga, mniej znana odsłona tego korespondencyjnego dialogu. W roli pośrednika pojawi się w niej Lipski.

Nic nie wiadomo o ewentualnych przedwojennych kontaktach Lipskiego z Gombrowiczem. Dla aspirujących do świata literackiego nastolatków, do jakich zaliczał się w latach 30. Lipski, starszy o ponad dekadę Gombrowicz stanowił jednak kluczowy punkt odniesienia ${ }^{27}$. Było tak chociażby w przypadku studenta prawa UW Kazimierza Brandysa, który bywał przy stoliku Gombrowicza w Ziemiańskiej i być może należał też do kręgu znajomych

23 R. Gombrowicz Gombrowicz w Argentynie, s. 162.

24 Tamże, s. 163.

25 Tamże, s. 162.

26 O twórczości Gombrowicza w kontekście Levinasowsko-Buberowskiej "filozofii spotkania” zob. J. Olejniczak Podmiot(y) Gombrowicza, w: Kłamstwo nieprzerwane nas drąży: cztery szkice o Gombrowiczu, Wydawnictwo Uniwersytetu Śląskiego, Katowice 2003, s. 65-114.

27 Zob. J. Tomkowski Pokolenie Gombrowicza. Narodziny powieści XX wieku w Polsce, Czytelnik, Warszawa 2001. 
Lipskiego ${ }^{28}$. Ten ostatni wspominał po latach o „znakomitej recenzji Ferdydurke"29, jaką napisał Schulz ${ }^{30}$, choć nie ma pewności, czy zapoznał się z nią już przed wojną, czy wiedzę tę zyskał w jakiś sposób później (Gombrowicz wzmiankuje o poparciu ze strony Schulza w jednym z listów do Lipskiego, o czym dalej). W chwili wybuchu wojny Gombrowicz był już autorem zbioru opowiadań (Pamiętnikz okresu dojrzewania), powieści (Ferdydurke), wydawanej pod pseudonimem powieści w odcinkach (Opętani), dramatu (Iwona, księżniczka Burgunda) oraz serii reportaży i szkiców krytycznoliterackich, który to dorobek zagwarantował mu rangę jednego z najważniejszych i najchętniej komentowanych głosów nowego pokolenia w literaturze. Siłą rzeczy musiał znajdować się na horyzoncie początkujących pisarzy takich jak Lipski - debiutujący (jeszcze pod nazwiskiem Lipschütz) jako nastolatek w 1932 roku - którego przedwojenny dorobek ograniczał się do drukowanych głównie w niskonakładowych i efemerycznych periodykach fragmentów próz, mikroopowiadań, eksperymentalnych „egotyków”, esejów i recenzji.

Sieć literackich układów i hierarchii całkowicie unieważni jednak wojna. Jej wybuch zastanie Gombrowicza w Argentynie, gdzie pisarz spędzi kolejne 24 lata, nim wróci do Europy. Lipski, uciekający z grupą krakowskich znajomych przed wojskami Wehrmachtu, znajdzie się w tłumie „bieżeńców” w okupowanym przez Armię Czerwoną Lwowie, skąd zostanie deportowany do łagrów, aby następnie, po amnestii, przejść szlak Armii Andersa i przez Iran oraz Liban dotrzeć do Palestyny. To właśnie na Bliskim Wschodzie trawiony chorobami Lipski dozna w 1945 roku paraliżu oraz afazji. Lipski zapomina macierzystego niemieckiego, a także francuskiego i dopiero po kilku latach rekonstruuje swój wyuczony język ojczysty - polski ${ }^{31}$. Utknąwszy

obraz terytoria, Gdańsk
t. 12 z. $96-98$, s. $183-189$.

31 Jednym z bohaterów omawianej korespondencji jest sam język, a nawet relacja pisarza na wygnaniu wobec języka. Rozmowa ta toczy się przecież między twórcami rozrzuconymi po świecie, znajdującymi się na innych półkulach, między Buenos Aires a Jerozolimą, z postojem w Tel Awiwie. Uczestniczy w niej urodzony w Zurychu Lipski, pół-Austriak z pochodzenia, który spędził młodość w Krakowie, by teraz odgruzowywać polszczyznę po afazji; przebywający na emigracji w Argentynie Gombrowicz, którego Ślub ukazał się pierwotnie po hiszpańsku, w języku, którym posługiwał się wówczas na co dzień; a także piszący swoje książki po niemiecku wiedeńczyk Buber, który wynosi z domu także umiejętność mówienia w jidysz i po 
w Palestynie w dramatycznej sytuacji socjalnej i zdrowotnej, skrajnie wyalienowany z otoczenia (nie nauczy się nigdy hebrajskiego), w swoim „maksimum wygnania" ${ }^{32}$ inwalida Lipski postanawia wrócić do literatury, posługując się jednak wyłącznie polszczyzną. Pierwsze kontakty z emigracyjnymi ośrodkami kultury polskiej nawiązuje jeszcze pod koniec lat 40., kiedy to kończy powieść Niespokojni, którą bezskutecznie próbuje zainteresować wydawców. To na tamten czas datuje się m.in. ożywiona korespondencyjna znajomość z Chmielowcem. Z zachowanych w toruńskim Archiwum Emigracji listów, które nie były dotąd publikowane, wynika, że Lipski w swoim izraelskim osamotnieniu, oddalony od głównych centrów emigracyjnego życia, rozpaczliwie próbuje być na bieżąco ze zjawiskami pojawiającymi się w ówczesnej kulturze polskiej. Śledzi więc rozbłyskującą na nowo gwiazdę Gombrowicza, czytając Trans-Atlanty) $k^{33}$, a następnie Ślub. Wydanie zbierające obydwie książki

polsku. Pierwszy list do Bubera Gombrowicz pisze w języku, którym posługiwał się doskonale od dzieciństwa, po francusku. Na polski, który stanie się odtąd jedynym (poza drobną wstawką w jednym z listów) językiem korespondencji wymienianej przez całe to trio, przejdzie Buber. Gombrowicz wielokrotnie komentuje zresztą i komplementuje jego wytwornie archaiczną polszczyznę, będącą reliktem dawnego języka i przepuszczoną na dodatek przez filtr wyrafinowanej kaligrafii. Rękopiśmienny charakter listów Bubera odróżnia je od pisanych przez dwóch pozostałych aktorów tego dramatu, którzy wysyłają maszynopisy. Co więcej, w przypadku dotkniętego paraliżem i afazją Lipskiego nie jest pewne, czy dodatkowym filtrem nie była pomoc osób trzecich.

32 Tą znakomitą formułą w nieopublikowanej recenzji Piotrusia posłużyła się Ingeborg Bachmann w Ein Maximum an Exil (über Leo Lipski), w: tejże Kritische Schriften, Piper Verlag, München 2005, s. 439-449. Cyt. za: A. Lipszyc Leo Lipski, s. 70. W twórczości Bachmann dałoby się może odnaleźć zdumiewające ślady wpływu Lipskiego. Tytułowy bohater Maliny jest "autorem Apokryfu", a taki właśnie podtytuł nosi Piotruś. Wiele wskazuje na to, że Lipski pozostawał z Bachmann w bezpośrednim kontakcie. Przyjaźnił się z jej ówczesnym partnerem życiowym, Adolfem Oplem, którego upoważnił do "prowadzenia rozmów z wydawcami" w sprawie publikacji obcojęzycznych przekładów swoich książek. To właśnie Opel, jak podaje Lipski, miał zainteresować jego książkami innych pisarzy, wśród nich Güntera Grassa i właśnie Bachmann; por. listy Leo Lipskiego do Jerzego Giedroycia, 05.07.1967 roku oraz 20.07.1967 roku, w: Listy do redakcji, ILK KOR RED Lipschutz L, Archiwum Instytutu Literackiego "Kultura” w Maisons-Laffitte. Bachmann jest zresztą kolejną osobą łączącą Lipskiego i Gombrowicza. Wraz z tym drugim znalazła się wśród pierwszych stypendystów Fundacji Forda w 1963 roku. Zob. wspomnienie Bachmann o ich wspólnym pobycie w Berlinie: R. Gombrowicz Gombrowicz w Europie, Wydawnictwo Literackie, Kraków 2008, s. 170-174.

W sierpniu 1953 roku jest już po jego lekturze, skoro wspomina o błędzie, jaki popełnił w "ocenieniu teoretycznym" powieści. List Leo Lipskiego do Michała Chmielowca, 23.08.1953 roku, Archiwum Emigracji w Toruniu. Za udostępnienie korespondencji z Chmielowcem serdecznie dziękuję Oldze Osińskiej. 
przywiezie do Izraela znajomy Lipskiego, Julius Margolin: „będę nareszcie to mógł przeczytać" - raportuje Chmielowcowi pisarz ${ }^{34}$. Z listów wynika, że Trans-Atlantyk był dla Lipskiego tematem rozmów z Margolinem, który zabierał się nawet wówczas za tłumaczenie fragmentów powieści ${ }^{35}$. Ogólny zamysł Gombrowicza, by przywołać po latach początki swojego pobytu w Argentynie, skojarzył się zresztą Lipskiemu z Niespokojnymi, rekonstrukcją przedwojennych losów grona najbliższych mu osób, skoro w liście do Chmielowca określa swoją powieść „Krupami ciężkimi moimi” - tymi samymi słowami, które pojawiają się w pierwszych linijkach Trans-Atlantyku $u^{36}$. Odnotowuje też uwagę z listu Jeleńskiego, który, jak zaznacza, będąc już po lekturze Gombrowicza i Miłosza, miał uznać Niespokojnych za ,jedną z najwybitniejszych rzeczy współczesnych polskich"37. To w tym liście Lipski rzuca lapidarnie: „Do Gom., zdaje się, napiszę"

Zachęta do korespondencji wyszła jednak od Gombrowicza. Chmielowiec przesłał mu uwagi, jakie o jego pisaniu formułował w jednym z listów Lipski ${ }^{39}$. Wiemy o tym od samego Lipskiego, który cytował po latach urywek listu Gombrowicza do Chmielowca, przekazany autorowi Piotrusia najpewniej przez tego ostatniego (żadnego z listów nie udało się, niestety, na razie odnaleźć): „bardzo jestem wdzięczny za list Lipskiego, to takie opinie, nie do autora adresowane, to jedyne swobodne, jedyne ważne. Poza tym ten list podbił mnie czymś nieuchwytnym - motus animi continuus ${ }^{40}$, jeśli moja łacina

List Leo Lipskiego do Michała Chmielowca, 01.111953 roku, Archiwum Emigracji w Toruniu. Chodzi o "dwupak" wydany nakładem Instytutu Literackiego w 1953 roku.

List Leo Lipskiego do Michała Chmielowca, 04.04.1954 roku, Archiwum Emigracji w Toruniu.

List Leo Lipskiego do Michała Chmielowca, 09.11.1954 roku, Archiwum Emigracji w Toruniu. Na paralelność obydwu projektów Lipski wskazywał już wcześniej: „równocześnie ze mną idzie Gom.." List Leo Lipskiego do Michała Chmielowca, 01.111953 roku, Archiwum Emigracji w Toruniu.

List Leo Lipskiego do Michała Chmielowca, 04.04.1954 roku, Archiwum Emigracji w Toruniu.

Tamże. W podobnej tonacji gdzie indziej: „Odpiszę, myślę”. List Leo Lipskiego do Michała Chmielowca, 26.09.1954 roku, Archiwum Emigracji w Toruniu. Dystans wynikał tu być może z pragnienia zachowania w relacji z Gombrowiczem jakiejś dozy autonomii oraz z niechęci do odgrywania wyłącznie roli jego bezkrytycznego akolity. Zob. uwagę Lipskiego o Gombrowiczowskim pojęciu formy, które nazywa „mętnym”. List Leo Lipskiego do Michała Chmielowca, 28.06. [brak daty rocznej, kontekst wskazuje na rok 1953], Archiwum Emigracji w Toruniu.

Odbyło się to za zgodą samego Lipskiego. List Leo Lipskiego do Michała Chmielowca, 01.11.1953 roku, Archiwum Emigracji w Toruniu.

Motus animi continuus (łac.) - 'ustawiczny ruch ducha'. 
mnie nie zawodzi" ${ }^{\prime 4}$. Gombrowicz został chyba poinformowany przez Chmielowca o stanie zdrowia Lipskiego, skoro prosząc o kontakt, jak podkreślał, nie chciał go niepokoić w chorobie.

W takich okolicznościach Lipski inicjuje interesujący nas dialog. Dochodzi do niego w czasie dla obydwu biografii przejściowym. Obydwaj pisarze dalecy są jeszcze od zajęcia miejsc na literackim parnasie. Oczywiście i tu panuje asymetria. Gombrowicz to wzrastający gigant, jego wydane właśnie książki oraz zainicjowany chwilę wcześniej Dziennik uruchomią procesy, dzięki którym wysforuje się do rangi jednej z czołowych postaci polskiej kultury. Lipski jest w tym czasie ledwie autorem przedwojennych juweniliów i istniejącej w maszynopisie powieści, która zresztą nie ukaże się za jego życia. Równocześnie jednak to dialog dwóch twórców, których „bycie w literaturze" dalekie jest od oczywistości. Jeden wrócił do pisania po latach, by jako urzędnik bankowy uprawiać je z konieczności jedynie obok obowiązków zawodowych zapewniających mu minimum środków do przeżycia, drugi, wegetujący w upiornych warunkach inwalida, także zaczął pisać na nowo i bezskutecznie zabiega o wydanie swojej powieści.

„Sprawa Bubera”, która stanie się głównym tematem tej korespondencji, pojawi się dopiero na marginesie pierwszego z listów („Czy mógłby Pan sprawić, aby obszedł go Trans-Atlantyk?" "22). Jego zasadniczą i najbardziej pasjonującą część wypełniają porady, jakich udziela Lipskiemu Gombrowicz, wychodząc od diagnoz na temat stosunku tego pierwszego do pisania: „Mnie się zdaje, że Pan nie umie pogodzić się z tym, że się pisze tylko częścią swojej istoty. [...] Mam też wrażenie, że Pan sobie utrudnia pisanie - a trzeba sobie ułatwiać" "43. Dodajmy, że te całkiem chyba przenikliwe hipotezy Gombrowicz stawia, dysponując znikomym materiałem dowodowym. Jedynym tekstem Lipskiego, jaki wówczas zna, jest list, który od niego otrzymał. Niespokojni istnieją wówczas wyłącznie w rękopisie, kontakt z Jerzym Giedroyciem i Instytutem Literackim w Maisons-Laffitte, gdzie dopiero za kilka lat opublikuje Piotrusia, Lipski nawiązał niecały rok wcześniej ${ }^{44}$. Trudno też przypuszczać,

41 Cyt. za: L. Lipski, Paryż ze złota, s. 179.

42 List Witolda Gombrowicza do Leo Lipskiego, 30.07.1954 roku.

43 Tamże.

44 Losy obydwu pisarzy splotą się w 1960 roku, kiedy w serii „Kultury” ukażą się jednocześnie Pornografia i Piotruś. Reakcje na książkę Lipskiego Giedroyc będzie zresztą zestawiał z tymi na powieść Gombrowicza. List Jerzego Giedroycia do Leo Lipskiego, 12.10.1960 roku, w: Listy do redakcji: „Piotruś wywołuje (prawie jak Gombrowicz) poruszenie i niezmiernie sprzeczne opi- 
by Gombrowicz znał jego juwenilia, które Lipski wydawał, nie ukrywając się jeszcze pod pseudonimem ${ }^{45}$. Wbrew temu, co sugeruje Chmielowcowi Lipski („[Gombrowicz] nie wie, że piszę. O d kry wa mnie. Nie zrozumiał intencji listu"46), Gombrowicz zdaje sobie chyba sprawę, że jego rozmówca ma za sobą jakieś próby literackie („żałuję, że na dystans nie mogę przydać się Panu w przezwyciężeniu oporów, które Pana zahamowały w literaturze”). Co więcej, zachęca do kolejnych: „odnoszę wrażenie z tych niewielu zdań Pańskich, jakie mnie dobiegły, że Pan jest powołany do pisania" "47. Da się przy tym wysłyszeć dość niecodzienny dla Gombrowicza ton, w którym pochwały nie są chyba dyktowane wyłącznie kurtuazją i chęcią wykorzystania Lipskiego do akcji „Buber”, ale znakomitym słuchem, każącym sądzić, że po drugiej stronie znajduje się pisarz potencjalnie potężnego formatu:

„jest coś w Pańskim sposobie wyrażania się nader godnego uwagi - w samym kształcie zdania, a może w rytmie. Tak mi się zdaje przynajmniej. Pańskie słowo jest bardzo silnie związane z Pańskim życiem wewnętrznym, to się czuje. Mam wrażenie, że w Panu jest materiał na stylistę i to z tych głębszych"48.

Dopiero w drugim z listów Gombrowicz przechodzi we właściwy sobie tryb zarządzania literackim powodzeniem: „niech Pan z łaski swojej da $\mathrm{Bu}-$ berowi Trans-Atlantyk, możliwie jak najprędzej, i z listem, który by go zachęcił do przeczytania prędkiego" ${ }^{\text {, }, ~ „ m o z ̇ e ~ n i e c h ~ P a n ~ m u ~ w s p o m n i, ~ z ̇ e ~ m a m ~ j u z ̇ ~}$ i poważnych popleczników w Paryżu. [...] Proszę mu coś powiedzieć o moim Dzienniku”50. Mówiąc o swoim zainteresowaniu Buberem („do tego człowieka

nie". Lipski, który otrzymywał publikacje „Kultury”, dostał najpewniej także książkę Gombrowicza, choć przypuszczenia tego nie udało się dotąd przekuć w pewność. Podziękowania za przesłanie mu Piotrusia składał za to Giedroyciowi Gombrowicz. J. Giedroyc, W. Gombrowicz Listy 1950-1969, wyb. i oprac. A.S. Kowalczyk, Czytelnik, Warszawa 2006, s. 445.

Choć Gombrowicz zdradza się ze znajomością jego nazwiska. Zob. R. Gombrowicz Gombrowicz wArgentynie, s. 165.

List Leo Lipskiego do Michała Chmielowca, 26.09.1954 roku, Archiwum Emigracji w Toruniu.

List Witolda Gombrowicza do Leo Lipskiego, 30.07 .1954 roku.

List Witolda Gombrowicza do Leo Lipskiego, 21.09.1954 roku.

Tamże.

Tamże. 
mam nabożeństwo”51) i powinowactwie, jakie odczuwa z jego myślą („kuzyn duchowy" ${ }^{52}$ ), Gombrowicz zwierza się jednocześnie z rozczarowania: „to nie jest mó j czytelnik - mo i biorą we mnie udział. Buber nie stowarzysza się ze mną, z moim gatunkiem dramatu, poezji czy rozkoszy"53.

Ze wszystkich tych zabiegów niewiele wynikło poza zdawkową opinią wystawioną przez Bubera po francusku, którą Gombrowicz miał się posługiwać w swoich staraniach o zainteresowanie wydawców: „Polski pisarz Witold Gombrowicz jest znakomitym autorem o silnym, męskim, nieposkromionym talencie, bez potknięć i zająknięć. Należy go tłumaczyćn"54. Dwa tygodnie później, 15 lutego 1955 roku, Gombrowicz wysłał jednocześnie listy do Bubera i Lipskiego, które stanowią finalny akt całej sprawy.

Jeśli chodzi o relacje, jakie na jej temat pozostawił Lipski, dotychczas znana była jedynie jego wypowiedź wygłoszona po śmierci Gombrowicza, a zamieszczona w liście drukowanym w Paryżu ze złota:

Za najwybitniejsze rysy twórczości Gombrowicza uważam niepowtarzalność, wysoki poziom intelektu, odrębność i odwagę. Był to pisarz, który się - jedyny wśród współczesnych - wyrwał z polskości, nie przestając być polski. Gdybym pisał historię polskiej literatury, to przeznaczyłbym dla Gombrowicza 15 stron, tyle co dla Słowackiego, Norwida, Leśmiana, Witkacego, Schulza; Mickiewiczowi dałbym dwadzieścia. ${ }^{55}$

Kwerenda w Archiwum Instytutu Literackiego w Maisons-Laffitte, obejmująca niebadaną dotychczas korespondencję Lipskiego z Giedroyciem, pozwala stwierdzić, że w podobnym tonie wypowiadał się on już kilka miesięcy wcześniej, natychmiast reagując na zgon Gombrowicza: „zmarł Gombrowicz, może najwybitniejszy polski pisarz współczesny, a na pewno najoryginalniejszy [...] Jest to wielka strata dla naszej emigracyjnej kultury, choć on od dawna był czymś więcej niż tylko emigracyjnym pisarzem"56.

51 Tamże.

List Witolda Gombrowicza do Leo Lipskiego, 28.12.1954 roku. Tamże.

R. Gombrowicz Gombrowicz w Argentynie, s. 169.

L. Lipski Paryżze złota, s. 178. 
To wówczas też Lipski informuje redaktora „Kultury” o przechowywanych przez siebie materiałach na temat Gombrowicza:

Ja osobiście posiadam trzy czy cztery Jego listy z czasów, kiedy polowaliśmy na grubego z wierza - jak On to nazywał - Martina Bube$\mathrm{ra}^{57}$. I ja mam też, o dziwo, autentyczną, po polsku pisaną, opinię Bubera o Trans-Atlantyku (pośredniczyłem w tym). Fotokopiami tego mógłbym Panu służyć. Postaram się, jeśli to będzie dla mnie możliwe, parę słów o tych kontaktach napisać. ${ }^{58}$

Giedroyc, który nosił się w tamtym czasie z zamiarem wydania tomu korespondencji Gombrowicza, wyraził zainteresowanie materiałami, prosząc o ich przesłanie ${ }^{59}$. Na drodze stanęły jednak kłopoty techniczne: „oryginały listów są, moim zdaniem, non transportables - pisane na bibule plus kilkanaście lat leżenia w tutejszym wilgotnym klimacie. Wiem też,że nie będzie Pan mógł zrobić reprodukcji z przesłanych Panu fotokopii"60.

To wówczas też Lipski załącza "notatkę wyjaśniająca, bez której ta korespondencja jest zupełnie niejasna"61. Ostatecznie pomysł opublikowania korespondencji Gombrowicza nie doszedł do skutku, przez co też prezentowane tu materiały nie miały okazji ujrzeć światła dziennego. Dodajmy dla ścisłości, że w archiwum w Maisons-Laffitte ocalały jednak nie fotokopie nadesłane przez Lipskiego, ale oryginały, które przetrwały próbę czasu i klimatu, a następnie zostały dostarczone do Giedroycia przez Agnieszkę Maciejowską̨ ${ }^{62}$. Dzięki temu to one mogły stać się podstawą poniższej edycji.

Określenie to pojawia się w: List Witolda Gombrowicza do Leo Lipskiego, 15.02.1955 roku.

58 List Leo Lipskiego do Jerzego Giedroycia, 02.08.1969 roku., w: Listy do redakcji.

59 List Jerzego Giedroycia do Leo Lipskiego, 22.08.1969 roku, w: Listy do redakcji.

60 List Leo Lipskiego do Jerzego Giedroycia, 15.09.1969 roku, w: Listy do redakcji.

61 Tamże.

62 List Agnieszki Maciejowskiej do Jerzego Giedroycia, 28.02.1999 roku, w: A r c h i w u m I n s ty tutu Literackiego "Kultura" w Maisons-Laffitte. 
Witold Gombrowicz (1904-1969) - twórca programu egzystencjalnego, którego celem była kompleksowa rewizja rozumienia jednostki i jej stosunku do kultury. Autor powieści (Ferdydurke, Trans-Atlantyk, Pornografia, Kosmos), opowiadań (Pamiętnik z okresu dojrzewania), dramatów (Iwona, księżniczka Burgunda, Ślub, Operetka) i dziennika, w których testuje założenia swojej nowatorskiej antropologii. Od 1939 roku na emigracji w Argentynie, powróci do Europy w 1963 roku, by następnie osiąść na stałe we Francji. Starania o literacką Nagrodę Nobla przerwie jego śmierć.

Leo Lipski (1917-1997) - urodzony w Szwajcarii polski pisarz pochodzenia żydowskiego. Debiutował przed wojną jako autor opowiadań. Zesłany do łagrów, wydostaje się z ZSRR wraz z armią Andersa. Podczas wędrówki przez uchodźczy szlak na Bliskim Wschodzie doznał paraliżu i utraty mowy. Resztę życia Lipski spędził w Izraelu, żył w dramatycznych warunkach socjalnych. W tych okolicznościach powstaje mikropowieść Piotruś, gdzie drastyczne doświadczenie inwalidztwa zostaje przepuszczone przez filtr heretyckiej teologii. Powieść Niespokojni ukazała się po śmierci autora.

\section{Listy}

30.07.1954

\section{Drogi Panie,}

bardzo się ucieszyłem listem od Pana. Ale obawiam się, że niepotrzebnie sprowokowałem Pana do pisania, co może Pana zmęczyło. Korespondencja jest rzeczą dosyć beznadziejną, gdyż nadaje się tylko do spraw konkretnych, praktycznych - inne nie mieszczą się na papierze listowym.

Żałuję, że na dystans nie mogę przydać się Panu w przezwyciężeniu oporów, które Pana zahamowały w literaturze. Odnoszę wrażenie z tych niewielu zdań Pańskich, jakie mnie dobiegły, że Pan jest powołany do pisania. Poradziłbym Panu, żeby zaczął pisać byle co i byle jak - a najlepiej rzeczy krótkie. Choćby nawet Pana zupełnie nie zadowalały. To da Panu bazę formalną, będzie punktem wyjścia. Literatura to redukcja - to znaczy, że tylko niewielki procent tego, co w nas jest, może być zużytkowany. Mnie się zdaje, że Pan nie umie pogodzić się z tym, że się pisze tylko częścią swojej istoty. Niech Pan wejdzie byle jak w te tryby i pozwoli, żeby one Pana urobiły.

Mam też wrażenie, że Pan sobie utrudnia pisanie - a trzeba sobie ułatwiać. Niech Pan wyjdzie z założenia, że pisać jest łatwo. Ale być może trafiam, jak kulą w płot - znam Pana tak mało.

Co do Pańskiej reakcji na moją literaturę - czy Pan nie wsadza w nią za wiele z siebie samego? Zgadzam się, że to jest dosyć „trujące”, ale chyba o tyle tylko, o ile sama rzeczywistość... a nawet myślę, że ja, przezwyciężając, o ile się da, tą rzeczywistość humorem i zabawą, zdecydowany bawić się wbrew wszystkiemu, a zresztą także zapraszając do wykorzystania wszystkich 
możliwości, które dla twórczości i postępu się tu nasuwają, jestem o wiele mniej „destrukcyjny” od wielu innych.

Jeżeli Pan będzie miał ochotę, proszęjeszcze odezwać się - ale tylko w tym wypadku, gdyby to w Panu było spontaniczne. „Odpisywanie na listy” jest między nami zbędne.

Pozdrowienia

[Dopisek ręczny - P.S.]: Czy Pan jest w kontakcie z Buberem? W swoim czasie przesłałem mu Ślub ${ }^{63}$; otrzymałem od niego list ${ }^{64}$. B.[ardzo] go cenię. Czy mógłby Pan sprawić, aby obszedł go Trans-Atlantyk? (On umie po polsku).

\subsubsection{4}

Drogi Panie Leo,

bardzo to miłe z Pańskiej strony, że Pan o mnie nie zapomina. (To zdanie wypadło mi po pensjonarsku, ale trudno, już napisane). Jest coś w Pańskim sposobie wyrażania się nader godnego uwagi - w samym kształcie zdania, a może w rytmie. Tak mi się zdaje przynajmniej. Pańskie słowo jest bardzo silnie związane z Pańskim życiem wewnętrznym, to się czuje. Mam wrażenie, że w Panu jest materiał na stylistę, i to z tych „głębszych".

List Pana zastał mnie mocno zdeprymowanym, gdyż właśnie otrzymałem wiadomość z Paryża, że Julliard (wydawnictwo) odrzucił moją Ferdydur$k e^{65}$. To rozpacz i katastrofa. Ta książka ma swoich zwolenników w Paryżu, i to poważnych, usiłowali narzucić ją Julliardowi Nadeau ${ }^{66}$ i Bondy ${ }^{67}$, a jednak

63 List Witolda Gombrowicza do Martina Bubera, 03.05.1951 r., w: R. Gombrowicz Gombrowicz wArgentynie, Wydawnictwo Literackie, Kraków 2005, s. 162.

64 List Martina Bubera do Witolda Gombrowicza, 09.07.1951 r., w: R. Gombrowicz Gombrowicz wArgentynie, s. 162163.

65 Julliard - wydawnictwo francuskie, które początkowo odmówiło wydania przekładu Ferdydurke. Powieść ukaże się jednak w tym wydawnictwie w 1958 roku.

66 Maurice Nadeau - krytyk literacki, jeden z największych orędowników twórczości Gombrowicza we Francji. Doprowadził m.in. do wydania Ferdydurke w wydawnictwie Julliard w 1958 roku. Zob. wspomnienie Nadeau o Gombrowiczu w: R. Gombrowicz Gombrowicz w Europie, S. 95101.

67 François Bondy - publicysta, pisarz i wydawca, jeden z największych promotorów pisarstwa Gombrowicza w niemieckim i francuskim obszarze językowym. Zob. np. wspomnienie Bondy'ego o Gombrowiczu w: tamże, s. 71 90, a także korespondencję z Gombrowiczem w: Gom- 
nic nie dało się zrobić, gdyż pod względem finansowym jest ryzykowna. Poprzednio - list od Camusa, który też mnie popiera, że nie widzi możliwości puszczenia tego w Gallimardzie ${ }^{68}$. Wszystko to razem usposabia mnie melancholijnie. Jestem przekonany, że gdyby moje rzeczy ukazały się po francusku, sytuacja moja znacznie by się wzmocniła. Już miałem recenzje w prasie francuskiej (na podstawie wydania hiszpańskiego) kwalifikujące Ferd.[ydurke] jako "genialną" etc. A ja tu tkwię w Argentynie, w banku, zakopany żywcem.

Cały ten przydługi wstęp zmierza do następującej prośby: niech Pan, z łaski swojej, da Buberowi Trans-Atlantyk możliwie jak najprędzej i z listem, który by go zachęcił do przeczytania prędkiego (może niech Pan napisze, że mu Pan wypożycza tylko na miesiąc). Do tego człowieka mam nabożeństwo, bo pewne rzeczy, które napisał, bardzo mi były przydatne. A poza tym mam wrażenie, że jedynych prawdziwych przyjaciół znajdę wśród Żydów ${ }^{69}$. Dwaj ludzie, którzy naprawdę mnie poparli w literaturze polskiej, to Schulz ${ }^{70}$ i Wittlin ${ }^{71}$. Otóż gdyby Opatrzność w niezbadanych wyrokach swoich sprawiła, że Bubera zdobyłby Trans-Atlantyk (on poprzednio pisał mi o Ślubie, ale przebijało się z listu, nader kurtuazyjnego, że dla niego ten dramat nie jest

browicz - walka o sławę: korespondencja, cz. 2: Witold Gombrowicz, Konstanty A. Jeleński, François Bondy, Dominique de Roux, Wydawnictwo Literackie, Kraków 1998.

68 Albert Camus - pisarz francuski, laureat Literackiej Nagrody Nobla za rok 1957. Gombrowicz, który nieszczególnie cenił jego pisarstwo, znając pozycję Camusa w świecie paryskiego establishmentu intelektualnego, próbował jednak zainteresować go swoją twórczością. Otrzymał nawet "umiarkowanie pochwalny" list przesłany przez Camusa po lekturze Ślubu. Kontakt ten był szczególnie cenny także ze względu na to, że Camus był wówczas pracownikiem czołowego francuskiego wydawnictwa, jakim był Gallimard. Dramat został jednak odrzucony, o czym przesądziły może bliskie związki wydawnictwa (via Roger Caillois) z wyszydzaną przez Gombrowicza grupą literacką skupioną wokół argentyńskiego magazynu "Sur", w skład której wchodził m.in. Jorge Luis Borges. Nt. listu do Camusa zob. R. Gombrowicz Gombrowicz w Argentynie, s. 143-144; uwagi Gombrowicza o Camusie w: W. Gombrowicz Dziennik, Wydawnictwo Literackie, Kraków 2011, s. 68-72.

69 Zob. analogiczną uwagę w: W. Gombrowicz Wspomnienia polskie. Wędrówki po Argentynie, Wydawnictwo Literackie, Kraków 2011, s. 174.

B. Schulz Ferdydurke, w: Szkice krytyczne. Dzieła zebrane, t. 7, oprac. W. Bolecki i inni, słowo/ obraz terytoria, Gdańsk 2007, s. 141-149. Pierwodruk: B. Schulz Ferdydurke, "Skamander” 1938 t. 12 z. 96-98, s. 183-189.

71 J. Wittlin Apologia Gombrowicza, w: tegoż Orfeusz w piekle XX wieku, Wydawnictwo Literackie, Kraków 2000. Pierwodruk: J. Wittlin Apologia Gombrowicza , "Kultura” 1951 nr 7-8, s. 52-60. 
rzeczywisty - w tym się myli), zwróciłbym się do niego z prośbą, aby mnie poparł swoimi wpływami.

Może niech Pan mu wspomni, że mam już i poważnych popleczników w Paryżu i że walczę o przewekslowanie mojej literatury na tory bardziej europejskie. W ogóle im więcej Pan go poinformuje o mnie i o mojej „konstruktywnej" działalności wśród Polaków, tym lepiej. Proszę mu coś powiedzieć o moim Dzienniku.

Bardzo Pana przepraszam, Panie Leo, że gnębię Pana tymi nudnymi sprawami. Cóż mam robić? Co Pan myśli o moim dzienniku? Zastanawiam się, jak mam go rozwinąć i w jakim sensie - więc zdanie ludzi, jak Pan, jest dla mnie ważne. Łączę wiele pozdrowień.

\subsubsection{4}

Drogi Panie Leo, Przepraszam, że nie odpisałem na ostatni list. Właściwie odpisałem, ale zapomniałem wysłać. Załatwiam korespondencje w biurze, w warunkach nieco skomplikowanych.

Najserdeczniej dziękuję za Bubera. Z wielką ciekawością przeczytałem jego orzeczenie ${ }^{72}$. Otóż to nie jest „mój” czytelnik - „moi” biorą we mnie udział. Buber nie stowarzysza się ze mną, z moim gatunkiem dramatu, poezji czy rozkoszy - on się mnie przypatruje. Czy dobrze widzi? To jest wielka inteligencja, ale świat bardzo od mego oddalony.

Nie wierzę, aby Trans-Atlantyk doznawał jakiejś transmutacji w okolicach str. 134 - w tym, jak i w innych moich utworach, absurd stopniowo się wyzwala, dlatego moje rzeczy początkiem swoim mocniej tkwią w ziemi, a końcem - oszalałą głową - już dotykają boskiego nieba absurdu. Ale to jest h u m o r, a humor nigdy nie jest zupełnie oderwany od ziemi, jest szaleństwem, które się demaskuje.

Mam też wrażenie, że on nie docenia intelektualnej solidności mojego świata - jestem bardziej świadomy, skontrolowany, precyzyjny nawet, niż mniema.

Mnie on dlatego zainteresował, a nawet zafascynował, że na gruncie intelektualnym jest realizacją tego samego - w przybliżeniu - widzenia

72 Zob. L. Lipski Paryż ze złota: teksty rozproszone, wyb. i oprac. H. Gosk, Świat Literacki, Izabelin 2002, s. 170. 
człowieka. Jego książka Co to jest człowiek? ${ }^{\text {?3 }}$ dlatego stała mi się tak bliska ${ }^{74}$, [że] on za Feuerbachem ${ }^{75}$ wprowadza pojęcie „drugiego człowieka” („ty”, które ma uzupełnić „ja” idealizmu niemieckiego), tudzież jeszcze ważniejsze pojęcie „międzyludzkiego”. Byłem dość poruszony, gdy spostrzegłem, że idea, do której ja się zbliżyłem na własną rękę, tak gwałtownie ożywa pod tym piórem. Posłałem mu dramat, gdyż myślałem, że go zainteresuje sposób, w jaki ja wprowadzam to "ty” - poprzez formę w tym sensie, że forma człowieka stwarza się pomiędzy nim a innymi ludźmi jako coś trzeciego, coś, co nas wyznacza, nie będąc nami, co każe nam myśleć, czuć, reagować, w sposób niezgodny z naszym „ja”. Bo dla mnie człowiek wyraża się zawsze nie tak, jakby chciał, i stąd się bierze, że jest dla siebie niespodzianką - niespodzianką dynamiczną, tajemnicą twórczą.

Istniały pewne szanse, że B. [uber] uzna mnie za swego kuzyna duchowego, a wówczas mógłbym liczyć na jego istotne poparcie. Ale ja, w przeciwieństwie do dzisiejszej sztuki zorganizowanej, chcę robić sztukę bardziej mroczną, będącą bardziej wyładowaniem, intuicją, rozkoszą, zabawą, bólem, czymś, słowem, luźniejszym - zostawiam rozumowanie filozofom. I nastąpiło nieporozumienie, gdyż on sądzi, że to, co piszę, nie jest dość zorganizowane podczas gdy ja uważam, że ta swoboda pozwala osiągnąć inne wartości. Mam wrażenie, że gdyby B.[uber] znał mój Dziennik, to (pomijając wszystkie moje ewentualne naiwności filozoficzne) inaczej by mnie zobaczył.

Nie przypuszczam, aby on naprawdę mnie poparł. Mogłoby się to stać, tylko gdyby uznał, że moja artystyczna rzeczywistość mogłaby przysporzyć rezonansu i blasku jego myśli. Ale w każdym razie gdyby chciał mnie poprzeć w kołach niemieckich, byłoby [to] bardzo ważne. A ważniejsze jeszcze, gdyby mi ułatwił kontakt w Paryżu z ludźmi znającymi hiszpański, którym mógłbym przesłać Ferdydurke. I jeszcze coś, panie Leo, co pozostawiam Pańskiej rozwadze: myślę, że człowiek tego autorytetu ma kontakty ze światem wielkich finansów żydowskich, np. w Stanach. Sytuacja tak się przedstawia, że mnie wystarczyłoby 1000 dolarów na wydanie Ferdydurke po francusku. To suma drobna, a ja mam rzeczywiste i gorące poparcie wybitnych francuskich

73 Chodzi o Das Problem des Menschen (późniejsze wyd. polskie jako Problem człowieka), którą to książkę Gombrowicz czytał w przekładzie na hiszpański jako Qué es el hombre? (Co to jest człowiek?). jego pisma stanowiły jeden z krytycznych punktów odniesienia dla myśli Marksa i Engelsa. 
artystów i krytyków, nie mówiąc o „Kulturze” etc. Smutne, że muszę ubiegać się o to, ale jestem emigrant polityczny. Jeżeli Pan uważa, że można o tym pomówić z Buberem, proszę to zrobić.

Idzie o wydanie Ferdydurke po francusku. Ta książka jeszcze nie jest przetłumaczona na francuski - tylko fragmenty ukazały się w „Preuves"76. To mój utwór fundamentalny. Czy B.[uber] zna hiszpański? Nie mam pol [...]

[Dopisek ręczny - P.S.]: [...]skiego egzemplarza Ferd.[ydurke], ale mógłbym przesłać hiszpański. Nie chciałbym jednak zabierać mu czasu. Jeszcze raz b. [ardzo] dziękuję, Panie Leo, mam nadzieję, że Pan już wydobrzał z tej grypy.

\subsubsection{5}

Drogi Panie Leo,

dobre i to. W takich razach wszystko zależy od „losu szczęścia”. Napisałbym do niego wprost, jak Pan radzi, ale nie bardzo jestem pewny adresu - wobec czego załączam list. Dzięki jeszcze raz za tak przyjazną pomoc w łowach na grubego zwierza.

Co do Dziennika... Cytuję dla zabawy wyjątki z kilku listów otrzymanych ostatnio:

Giedroyc: „Pańskie dzienniki są znakomite, a nawet pasjonujące. Pan dopiero pokazał, co można zrobić z tą formą, tak zbanalizowaną przez następców Gide'a77 i rozmaitych Greenów ${ }^{78}$. Ten dziennik będzie może kamieniem węgielnym Pańskiej sławy"79.

76 "Preuves” - francuskie czasopismo kulturalno-polityczne, którego założycielem i redaktorem naczelnym w latach 1951-1969 był François Bondy.

André Gide - pisarz francuski, laureat Literackiej Nagrody Nobla za rok 1947, jeden z twórców modelu diarystyki, który stanowił dla Gombrowicza krytyczny punkt odniesienia.

78 Julien Green - pisarz francuski pochodzenia amerykańskiego, który przez całą swoją karierę literacką (1911-1998) prowadził dziennik wydany ostatecznie w 19 tomach.

79 Gombrowicz przeredagował tu następujący fragment: „Pana Dzienniki są jak zawsze doskonałe, a nawet pasjonujące, ale ostatnie jakby słabsze od poprzednich. Boję się, że to wynika z tego, że Pan nie docenia tej formy. Jest ona przez wszystkich Gide’ów i Greenów tak zbanalizowana, że dopiero Pan pokazuje, co z tego można zrobić. Ta forma może być kamieniem węgielnym Pana sławy"; zob. J. Giedroyc, W. Gombrowicz Listy 1950-1969, wyb. i oprac. A.S. Kowalczyk, Czytelnik, Warszawa 2006, s. 174. 
Jedna kobieta z Kanady: „Ostatnie dzienniki we mnie żadnej reakcji nie wzbudzają poza zdziwieniem, że Pan to pisze, a «Kultura» drukuje”.

Inna kobieta z Brazylii: „Podejrzewam w tym jakieś sztuczki magiczne, bo to nie może być, żeby Pan bez diabelskiej pomocy był tak w każdym słowie swoim odkrywczy".

No i pańska opinia. Co do mnie, nie potrzebuję na szczęście wić się w obieżach tak sprzecznych sądów, po prostu dlatego że nic innego w obecnych warunkach nie mógłbym pisać. Uważam jednak (szczerze mówiąc) ten dziennik za ważny. Dla mnie samego jest ważny, gdyż uruchamiam w nim pewne właściwości mojej istoty, które nigdy by nie znalazły wyrazu w czystej sztuce - i on "stwarza mnie" społecznie, towarzysko nawet, bardziej niż sztuka. A obiektywnie jest ważny, dlatego że w nim jest sporo nowego... Ale Pan wie, jak trudno jest komuś „postronnemu” ująć myśl w całej jej świeżości i we wszystkich jej możliwych konsekwencjach. Każdy z nas żyje własnymi myślami i czasem trudno przyzwyczaić się do cudzego myślenia. Ten dziennik może podziałać tylko na niektórych, takich, którym jest potrzebny.

I w ogóle - czyż wszelka sztuka nie opiera się tylko na kilku, kilkunastu, kilkuset pokrewnych organizacjach? Do pewnego stopnia bodaj rozumiem rozczarowanie, jakie wywołać musi w czytelniku Trans-Atlantyku coś takiego jak dziennik... A jednak jestem i ten, i tamten, nie chciałbym się ograniczyć do jednego tylko aspektu, jedno musi być uzupełnione drugim.

$\mathrm{Z}$ tego, co dotąd napisałem, najważniejsza wydaje mi się Ferdydurke. Dość tych zwierzeń. Serdeczne pozdrowienia. Czy Pan już wydobrzał?

\section{NOTATKA WYJAŚNIAJĄCA LEO LIPSKIEGO ${ }^{80}$}

W roku 1954 za pośrednictwem Michała Chmielowca ${ }^{81}$ nawiązałem kontakt z Witoldem Gombrowiczem. Z korespondencji naszej zachowało się kilka listów dotyczących określonej sprawy.

Chodzi tu mianowicie o pozyskanie Martina Bubera, w owym czasie profesora filozofii na Uniwersytecie Jerozolimskim, dla poparcia sprawy

80 Notatka dołączona do listu Leo Lipskiego do Jerzego Giedroycia, 15.09.1969, w: Listy do redakcji, ILK KOR RED Lipschutz L, Archiwum Instytutu Literackiego "Kultura” w Maisons-Laffitte.

81 Michał Chmielowiec - krytyk literacki, pisarz i publicysta związany z londyńskimi „Wiadomościami", w latach 1966-1974 ich redaktor naczelny. Przez wiele lat utrzymywał korespondencyjny kontakt z Lipskim. 
przekładu utworów Gombrowicza na język francuski. Gombrowicz, jak mi się wydaje, był w tym wypadku nieśmiały i dlatego posługiwał się moim, zbędnym zapewne, pośrednictwem.

Na jego prośbę komunikowałem się z Buberem. Muszę zaznaczyć, że Martin Buber, urodzony w Wiedniu, przez wiele lat profesor Uniwersytetu we Frankfurcie nad Menem i piszący po niemiecku, władał biegle i subtelnie językiem polskim i dlatego mógł czytać utwory Gombrowicza w oryginale; cała korespondencja odbywała się po polsku. Końcowy wynik usiłowań Gombrowicza nie zachował się u mnie, czego bardzo żałuję. Była to opinia o utworach Gombrowicza, w języku francuskim, sformułowana trochę jak szkolne świadectwo - notabene bardzo pochlebna i oceniająca twórczość Gombrowicza jako zjawisko na miarę międzynarodową ${ }^{82}$. Gombrowicz miał się tą opinią w swoich staraniach posługiwać. Był to jedyny sposób, w jaki Buber mógł pomóc Gombrowiczowi, gdyż, jak mi pisał, nie miał możliwości na rynku wydawniczym francuskim.

Listów Gombrowicza zachowało się u mnie cztery oraz jeden list Bubera, zawierający opinie o Trans-Atlantyku. Pozostałe listy Bubera wysłałem Gombrowiczowi; ten jeden zachowałem u siebie ze względu na niezwykły charakter całego tego epizodu.

[Do tekstu dołączony został przypis - P.S.]

Martin Buber (1878-1965); profesor filozofii Uniwersytetu we Frankfurcie nad Menem, później W Jerozolimie. Ogłosił m.in. Ich und du, 1923; Religion und Philosophie, 1931; Die Frage an den Einzelnen, 1936; Das Problem des Menschen, 1948; Bilder von Gut und Böse, 1952; Die Schriften über das dialogische Prinzip, 1954; Sehertum. Anfang und Ende, 1955; Königtum Gottes, 1956.

82 Zob. R. Gombrowicz, Gombrowicz w Argentynie, s. 169. 


\section{Abstract}

\section{Piotr Sadzik}

UNIVERSITY OF WARSAW

WitoldGombrowicz's Letters to Leo Lipski

The epistolary dialogue between Witold Gombrowicz and Leo Lipski is an overlooked episode in the history of Polish literature. Their correspondence began with the "Buber case," i.e. Gombrowicz's idea that Lipski should put him in touch with Martin Buber. The material presented here consists of hitherto unknown letters by Gombrowicz to Lipski, archived at the Kultura Literary Institute in the Parisian suburb Maisons-Laffitte, as well as a note in which Lipski details their relationship. To reconstruct the context of this correspondence Sadzik has also drawn on other previously unexamined materials, such as Lipski's correspondence with Jerzy Giedroyc (also at the Kultura archive) as well as the collection of the Archives of Polish Emigration in Torun.

\section{Keywords}

Witold Gombrowicz, Leo Lipski, Martin Buber, translation of Ślub [The Marriage] 